\title{
White Book of Institutional Intelligence: a collaborative effort to increase business intelligence maturity in HIGHER EDUCATION
}

Juan Jesús Alcolea ${ }^{1}$, Manuel Rivera $^{2}$

${ }^{1}$ Oficina de Cooperación Universitaria (www.ocu.es), Calle Arequipa, 1, 28043, Madrid, Spain, juanj@ocu.es

2Oficina de Cooperación Universitaria, Calle Arequipa, 1, 28043, Madrid, Spain, manuelr@ocu.es

Keywords

"Institutional Intelligence", "Business Intelligence", "White Book", "Higher Education", "University", "Data warehousing", "Data warehouse", "Academic analytics", "University analytics", "Analytics".

\section{INTRODUCTION}

The "White Book of Institutional Intelligence in Universities" will be the result of a collaborative effort of a cross-functional team uniting more than twenty persons from the Higher Education sector across eight countries, representing several different roles : management, administration, faculty, external government entities, specialized consultants, etc.

The goal of the book is to serve as a reference for institutions willing to acquire or evolve the institutional intelligence capability. The book tries to answer the most common questions any institution has to face when approaching institutional intelligence, for example:

- What is institutional intelligence and why should I care?

- What are the benefits? What are the risks?

- How does "success" look like?

- How should institutional intelligence be organized? Who are the stakeholders? What is their role and required level of involvement?

- How should the complex informational landscape of a higher education institution be approached?

- How is maturity in the institutional intelligence area measured? What are its most important aspects?

- What is the current state of the art? What are the expected short term innovations?

- What lessons can be learnt from institutions with successful institutional intelligence initiatives?

The English version of the book is due in late 2013 and will be freely distributed in electronic form.

\section{CONTENTS OF THE PRESENTATION}

In this talk we will present a summary of the contents and main conclusions of the book, as well as the lessons learnt during the project:

- Part 1: Presentation of the "white book" project. In this part, the project will be outlined, its main goals and guidelines presented, accompanied by some lessons learnt during the process.

- Part 2: Data as a strategic institutional asset - Institutional Intelligence. In the second part of the presentation, the concept of institutional intelligence will be presented, as well as its organizational implications and its current and short term expected results. 
- Part 3: Institutional Intelligence Maturity Model \& Case Studies. In this last part, a new institutional intelligence maturity model, specifically designed from scratch by "BI in HE" practitioners involved in the project, will be presented, along with the three "case studies" featured in the book, representing three Universities which have already traveled a long route towards institutional intelligence excellence.

\section{SHORT BIOGRAPHIES}

\section{Mr. Juan Jesús Alcolea}

Director of the Institutional Intelligence area.

Oficina de Cooperación Universitaria (OCU).

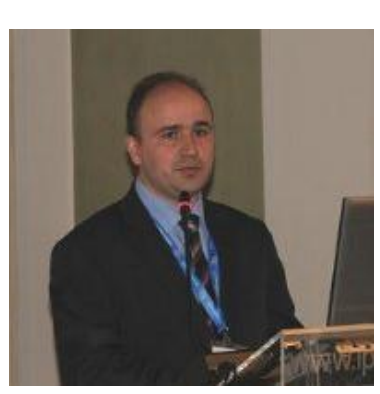

Started his career as an analyst/programmer in FORUM INFORMÁTICO $Y$ TECNOLÓGICO, where he spent several years involved in a project for developing an ERP system. After that, he joined the ALTRAN GROUP, where he worked as a BI consultant for the telecom sector for two years. In 2002 he started working for OCU as a BI Architect, being involved in several BI implementations in different Universities. Since 2008 he is the Director of the Institutional Intelligence area in OCU.

Qualified in Computer Engineering and with a Master degree in University Management, he has more than 15 years of experience as an IT professional.

\section{Mr. Manuel Rivera \\ Director of Communications.}

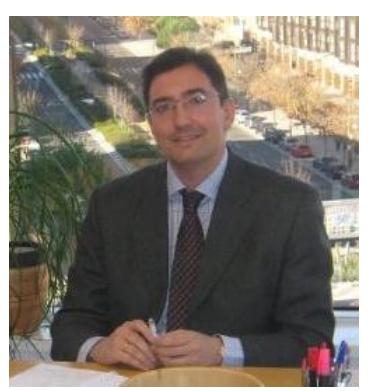

Oficina de Cooperación Universitaria (OCU).

Since 2009 he is responsible for corporate communications, marketing and institutional relations at OCU (Oficina de Cooperación Universitaria). Before that, since 2005, he was in charge of strategic customers relationships, coordinating several implementation projects of University Information Systems.

Qualified in Computer Engineering, with a Master degree in University Management, and numerous training courses in the field of marketing and customer relationships, he has more than 15 years of experience as an IT professional. 